\title{
Prevalence of fur mites (Acari: Atopomelidae) in non-human primates of Costa Rica
}

\author{
Adriana Troyo ${ }^{1}$, Mayra E. Solano ${ }^{1}$, Ólger Calderón-Arguedas ${ }^{1}$, Misael Chinchilla ${ }^{1,2}$, \\ Rónald Sánchez ${ }^{3}$ \& Gustavo A. Gutiérrez-Espeleta ${ }^{4}$ \\ 1. Centro de Investigación en Enfermedades Tropicales, Departamento de Parasitología, Facultad de Microbiología, \\ Universidad de Costa Rica, San José, Costa Rica; adriana.troyo@ucr.ac.cr, mayra.solano@ucr.ac.cr, \\ olger.calderon@ucr.ac.cr \\ 2. Departamento de Investigación, Universidad de Ciencias Médicas, San José, Costa Rica; \\ chinchillacm@ucimed.com \\ 3. Escuela de Biología, Sede de Occidente, Universidad de Costa Rica, Alajuela, Costa Rica; ronald.rsr@gmail.com \\ 4. Escuela de Biología, Facultad de Ciencias, Universidad de Costa Rica, San José, Costa Rica; \\ ggutier@biologia.ucr.ac.cr
}

Received 10-V-2008. Corrected 20-IX-2008. Accepted 27-X-2008.

\begin{abstract}
Parasites have been investigated for some New World primates; however, very little is known about ectoparasites and specifically fur mites. In this study, Alouatta palliata, Cebus capucinus, Saimiri oerstedii, and Ateles geoffroyi monkeys from different areas of Costa Rica were searched for fur mites. A total of 276 monkeys were evaluated, and 51 of them were positive for mites of the family Atopomelidae. Listrocarpus alouattae was identified on $22.3 \%$ of A. palliata; Listrocarpus capucinus on $12.8 \%$ of C. capucinus; and Listrocarpus costaricensis on $36.8 \%$ of $S$. oerstedii; No fur mites were found on A. geoffroyi. Sex was not considered a determinant of mite infestation, but prevalence was significantly higher in the Central Volcanic Mountain Range Conservation Area for L. alouattae $(\mathrm{p}=0.01)$ and in the Central Pacific Conservation Area for L. capucinus $(\mathrm{p}=0.002)$. These primate fur mites are highly host-specific. Differences in the geographical distribution may be due to monkey behavior and history, as well as to environmental conditions. Rev. Biol. Trop. 57 (1-2): 353-360. Epub 2009 June 30.
\end{abstract}

Key words: Atopomelidae, mite, Alouatta palliata, Cebus capucinus, Saimiri oerstedii, Ateles geoffroyi, Costa Rica.

The commonly recognized non-human primate species present in Costa Rica include Alouatta palliata Gray, 1849 (mantled howler monkey), Cebus capucinus Linnaeus, 1758 (white faced capuchin), Saimiri oerstedii Reinhardt, 1872 (squirrel monkey), and Ateles geoffroyi Kuhl, 1820 (spider monkey) (Rodriguez and Chinchilla 1996). A. palliata and $C$. capucinus can be found throughout the country and their specific geographical distribution, nutrition, and behavior have been investigated (Jones 1983, Happel 1986, Massey 1987, Lippold 1988, Zucker et al. 1996). In addition, copro-parasitological studies have shed some insight into the internal parasites of these primate species (Stuart et al. 1990, 1998). Recently, investigations have resulted in new reports and descriptions of endo and ecto parasites of primates in Costa Rica, which may have implications for the conservation of these species (Troyo et al. 2002, 2004, CalderónArguedas et al. 2004, Chinchilla et al. 2005a, 2005b, 2006, 2007).

Concerning ectoparasites, various arthropods have been associated with the hair and skin of primates. These include lice, fleas, flies, ticks and mites (Renquist and Whitney 1987, Colwell and Milton 1998). Fur mites of 
the family Atopomelidae have been described for some primate species. These fur mites have modifications on legs I and II, which allow them to hold on to the hairs of the host (McDaniel 1968, Krantz 1978). Eleven atopomelid species have been reported in New World primates of the families Cebidae and Callitrichidae, and all belong to the genus Listrocarpus Fain, 1967 (Fain 1979, Troyo et al. 2004). In Costa Rica, three species have been reported from primates: Listrocarpus alouattae Fain, 1972, from $A$. palliata; Listrocarpus capucinus Troyo et al. 2004, from C. capucinus; and Listrocarpus costaricensis Troyo et al. 2004, from S. oerstedii.

Associations between primates and their parasites may reveal information about their history, interactions and possible threats to survival (Nunn et al. 2004, Calderón-Arguedas et al. 2004, Pedersen et al. 2005, Chinchilla et al. 2005b). Given that ectoparasites like fur mites and lice depend highly on close contact between individuals for transmission and dispersal, the study of fur mites may reveal information about the social behavior of its host, as well as movement dynamics, distribution, and history (Bochkov et al. 2005, Bochkov and OConnor 2005, Reed et al. 2007). However, very little is known about the prevalence and ecology of atopomelid mites of primates. In this report, the distribution and prevalence of fur mites from primates in Costa Rica are analyzed.

\section{MATERIALS AND METHODS}

As part of a multidisciplinary study of non-human primates in Costa Rica, the presence of ectoparasites associated with the fur of monkeys was evaluated. The study included a sample of free ranging A. palliata, C. capucinus, $S$. oerstedii, and A. geoffroyi monkeys from national parks, and other protected and non-protected areas, as well as some individuals kept in captivity.

The collection, preparation and analyses of fur mite samples have been described previously (Troyo et al. 2002, 2004). Briefly, animals were sedated with Zoletil ${ }^{\circledR}(1: 1$ mixture of tiletamine and zolazepam administered at approximately $5 \mathrm{mg} / \mathrm{kg}$ ) and received on the ground with nets to protect them from physical harm as they fell from the trees. The place of origin, sex and primate species was noted for the monkeys evaluated. The individuals were combed, searched for ectoparasites, and a sample of hair was taken to the Laboratory of Medical Entomology at University of Costa Rica. When present, specimens were fixed in $70 \%$ ethyl alcohol, cleared and softened in lactophenol, and mounted in Hoyer's medium for observation and identification (Fain 1979, Troyo et al. 2004). Identification was performed using taxonomic keys and descriptions by Krantz (1978), Fain (1979), and Troyo et al. (2004). The specimens are deposited in the Arthropod Collection, Department of Parasitology, Faculty of Microbiology and the Insect Museum of the University of Costa Rica.

For the analyses, the information for the different locations evaluated was aggregated according to the eleven Conservation Areas established by the National System of Conservation Areas (Sistema Nacional de Áreas de Conservación) of Costa Rica. The data from the specific locations where fur mites were observed were used to determine (with chi-square or Fisher's exact tests) differences in fur mite prevalence for each of the monkey species according to the individual's sex and the area where observed. In addition, the same type of analysis was applied to determine differences in fur mite prevalence according to host species. Significance level was set at 0.05 for all of the analyses.

\section{RESULTS}

A total 276 monkeys from 24 locations of Costa Rica were evaluated for ectoparasites (Table 1). In 51 of them, fur mites from the family Atopomelidae were identified. All the fur mites collected belonged to the genus Listrocarpus, and two of the three species identified had been described for the first time as part of this interdisciplinary project on Costa Rican primates (Troyo et al. 2004). Each species of fur mite was associated to one single species 
TABLE 1

Monkeys evaluated for fur mites from different areas of Costa Rica

CUADRO 1

Monos evaluados por ácaros de pelo procedentes de diferentes zonas de Costa Rica

\begin{tabular}{lccccccccc}
\multicolumn{1}{c}{ Area } & \multicolumn{2}{c}{ Alouatta palliata } & \multicolumn{2}{c}{ Cebus capucinus } & \multicolumn{2}{c}{ Saimiri oerstedii } & \multicolumn{2}{c}{ Ateles geoffroyi } \\
& Total & Positive & Total & Positive & Total & Positive & Total & Positive \\
\hline GCA & 8 & 0 & 4 & 0 & 0 & 0 & 0 & 0 \\
TCA & 14 & 0 & 6 & 0 & 0 & 0 & 5 & 0 \\
ATCA & 22 & 0 & 5 & 0 & 0 & 0 & 0 & 0 \\
NHCA & 4 & 3 & 0 & 0 & 0 & 0 & 0 & 0 \\
CVCA & 21 & 13 & 6 & 0 & 0 & 0 & 2 & 0 \\
CPCA & 19 & 0 & 21 & 5 & 21 & 13 & 0 & 0 \\
ACCA & 28 & 11 & 0 & 0 & 0 & 0 & 0 & 0 \\
OCA & 12 & 4 & 4 & 1 & 15 & 1 & 1 & 0 \\
Gulf of Nicoya Islands & 11 & 0 & 0 & 0 & 0 & 0 & 0 & 0 \\
Captivity & 0 & 0 & 1 & 0 & 2 & 0 & 44 & 0 \\
Total & 139 & 31 & 47 & 6 & 38 & 14 & 52 & 0
\end{tabular}

GCA = Guanacaste Conservation Area; TCA = Tempisque Conservation Area; ATCA = Arenal-Tempisque Conservation Area; $\mathrm{NHCA}=$ North Huetar Conservation Area; $\mathrm{CVCA}=$ Central Volcanic Mountain Range Conservation Area; $\mathrm{CPCA}=$ Central Pacific Conservation Area; ACCA = Amistad-Caribe Conservation Area; OCA = Osa Conservation Area.

of monkey: of 139 A. palliata evaluated, 31 were positive for L. alouattae ( $22.3 \%$ infested); of 47 C. capucinus evaluated, 6 were positive for L. capucinus (12.8\% infested), and of 38 $S$. oerstedii evaluated, 14 were positive for $L$. costaricensis (36.8\% infested). None of the 52 A. geoffroyi evaluated presented fur mites.

The overall prevalence of fur mites in the primates did not reflect the situation observed for the few locations where fur mites were observed. L. alouattae was present in 53\% of the A. palliata from positive locations (31 infested of 60 monkeys evaluated), and infestation was as high as $80 \%$ in Nogal (Table 2). L. capucinus and L. costaricensis were only collected from locations in the Pacific areas of Costa Rica (Manuel Antonio and Corcovado). Considering only locations where the fur mites were found, $25 \%$ of $C$. capucinus (6 positive of 24 evaluated) and $44 \%$ of $S$. oerstedii (14 positive of 33 evaluated) were infested (Table 3 ).

In the locations where fur mites were observed, statistical analyses showed that sex was not associated with fur mite infestation in neither $A$. palliata (Chi-square test $\mathrm{p}=0.96$ ), C. capucinus (Fisher's exact test $\mathrm{p}=0.60$ ), nor $S$. oerstedii (Fisher's exact test $\mathrm{p}=0.54$ ). Fur mite positivity in A. palliata and $S$. oerstedii differed significantly depending on the area: prevalence of $L$. alouattae was higher in locations of the Central Volcanic Mountain Range Conservation Area (CVCA) compared to those of the Amistad-Caribe Conservation Area (ACCA) and Osa Conservation Area (OCA) (Chi-square test $\mathrm{p}=0.01$ ); and prevalence of $L$. costaricensis in $S$. oerstedii was higher in locations of the Central Pacific Conservation Area (CPCA) than those of the OCA (Chi-square test $\mathrm{p}=0.002$ ). There was no significant difference in positivity of $C$. capucinus between locations in the CPCA and OCA (Fisher's exact test $\mathrm{p}=0.71$ ). Overall, the three monkey species where fur mites were observed did not show significant differences in fur mite prevalence (Chi-square test $\mathrm{p}=0.17$ ). 
TABLE 2

Number of Alouatta palliata monkeys positive for Listrocarpus alouattae according to sex and location

\section{CUADRO 2}

Número de monos Alouatta palliata positivos parar Listrocarpus alouattae de acuerdo a sexo y localidad

\begin{tabular}{lccc}
\multicolumn{1}{c}{ Location } & \multicolumn{3}{c}{ Alouatta palliata } \\
& Males & Females & Total \\
$\begin{array}{lccc}\text { Cahuita National Park } \\
\text { (ACCA) }\end{array}$ & $2(7)$ & $2(10)$ & $4(17)$ \\
Puerto Vargas (ACCA) & $2(4)$ & $5(7)$ & $7(11)$ \\
Nogal (CVCA) & $8(10)$ & $4(5)$ & $12(15)$ \\
$\begin{array}{l}\text { Tirimbina (CVCA) } \\
\text { Corcovado National Park }\end{array}$ & $1(1)$ & $0(0)$ & $1(1)$ \\
(OCA) & $0(0)$ & $2(3)$ & $2(3)$ \\
Uvita (OCA) & $2(7)$ & $0(2)$ & $2(9)$ \\
Pital (NHCA) & $2(3)$ & $1(1)$ & $3(4)$ \\
Total & $17(32)$ & $14(28)$ & $31(60)$
\end{tabular}

ACCA = Amistad-Caribe Conservation Area; CVCA = Central Volcanic Mountain Range Conservation Area; OCA $=$ Osa Conservation Area; NHCA $=$ North Huetar Conservation Area. Values in parenthesis are total number of monkeys evaluated.

\section{DISCUSSION}

Fur mites of the family Atopomelidae were observed in three of the four species of non-human primates studied in Costa Rica. There were no fur mites recovered from $A$. geoffroyi monkeys. However, most of the individuals of this species that were evaluated were kept in captivity, and this condition may have negative effects on ectoparasites due to excessive grooming and/or antiparasitic treatments received at the sites. Moreover, no fur mites have been described to date from any of the Ateles species (Fain 1979), which may indicate a lack of fur mite adaptation to spider monkeys. In any case, further evaluations of free roaming Ateles are needed.

Although individuals of $A$. palliata, $C$. capucinus and $S$. oerstedii from different regions of the country were infested with fur mites, there were specific locations where most of the infestations were reported. Compared to L. capucinus and L. costaricensis, L. alouattae seemed to be more dispersed and was present in

TABLE 3

Number of Cebus capucinus monkeys positive for Listrocarpus capucinus and Saimiri oerstedii monkeys positive for Listrocarpus costaricensis according to sex and location

CUADRO 3

Número de monos Cebus capucinus positivos para Listrocarpus capucinus y monos Saimiri oerstedii positivos para Listrocarpus costaricensis de acuerdo a sexo y localidad

\begin{tabular}{lcccccc}
\multicolumn{1}{c}{ Location } & \multicolumn{3}{c}{ Cebus capucinus } & \multicolumn{3}{c}{ Saimiri oerstedii } \\
& M & F & Tot & M & F & Tot \\
Manuel Antonio National Park (CPCA) & $3(13)$ & $2(7)$ & $5(20)$ & $11(18)$ & $2(2)$ & $13(20)$ \\
Corcovado National Park (OCA) & $1(2)$ & $0(2)$ & $1(4)$ & $0(6)$ & $1(6)$ & $1(12)$ \\
Total & $4(15)$ & $2(9)$ & $6(24)$ & $11(25)$ & $3(8)$ & $14(33)$
\end{tabular}

$\mathrm{CPCA}=$ Central Pacific Conservation Area; $\mathrm{OCA}=$ Osa Conservation Area $\mathrm{M}=$ males, $\mathrm{F}=$ females, Tot $=$ total. Values in parenthesis are total monkeys evaluated. 
the Northern (North Huetar Conservation Area), Caribbean (Amistad-Caribe Conservation Area), Central (Central Volcanic Mountain Range Conservation Area) and South Pacific (Osa Conservation Area) regions of the country. Low levels of genetic variability in $A$. palliata from Costa Rica suggest a rapidly expanding small founder population (Zaldivar et al. 2003), which would also explain the mite distributions if founder populations already harbored the fur mites. In addition, although most of the areas where howler monkeys roam freely are now fragments of different sizes (Zaldivar et al. 2004), individuals were probably free to move from one area to the other in the past. During this time, contact between individuals and gene flow may have allowed dispersal of the fur mites. Close contact during grooming and mating, as well as between mothers and infants would be enough for mites to pass from one individual to another.

In the case of L. capucinus and L. costaricensis, the monkeys with fur mites were observed in two locations on the Pacific coast of Costa Rica: Manuel Antonio National Park and Corcovado National Park. The distribution of $S$. oerstedii in Costa Rica is restricted to Osa and Central Pacific Conservation Areas (Boinski and Sirlot 1997, Boinski and Cropp 1999, Zaldivar et al. 2004), which limits the dispersal of L. costaricensis. However, fur mites from C. capucinus, which is more widely distributed, were also restricted to Osa and Central Pacific Conservation Areas. This may suggest that infested populations in these locations might have been separated from uninfested populations in other regions of the country for longer periods of time, without close contact between distant geographical areas.

The fur mites were generally collected from monkeys in locations with high levels of humidity and rainfall like Manuel Antonio, Cahuita, and Corcovado National Parks. The body of atopomelid mites is very weakly sclerotized and, as with other families of the suborder Acaridida, respiration occurs through the tegument (Krantz 1978). Therefore, these mites are prone to desiccation and survival may depend on the conditions of their microhabitat. The presence of high humidity levels in many of the Costa Rican forests probably allows mite survival. However, the drier conditions of the Northern Pacific region may limit their survival and transmission, and could explain the apparent absence of fur mites in those A. palliata and C. capucinus populations. Other possible explanations for the absence of primate fur mites in the North Pacific (mainly Guanacaste and Tempisque Conservation Areas) could include slight behavioral differences in the hosts that may affect mite survival directly or indirectly such as grooming, food selection, and reduced contact between individuals.

According to these results and previous reports, fur mites of the genus Listrocarpus seem to possess strong host specificity. These host-parasite relationships can be the result of long periods of coevolution, and scientists have utilized this condition as a tool for taxonomic and phylogenetic studies of hosts and ectoparasites (Brum-Bittancourt and Duarte-Rocha 2003, Bochkov et al. 2005, Bochkov and OConnor 2005, Reed et al. 2007). The strong specificity of relationships between hosts and ectoparasites has been documented in other mites such as some of members of the families Sarcoptidae and Laelapidae. Other groups like ticks and macronyssid mites can be associated with a wider spectrum of possible hosts including birds, mammals and even man (Krantz 1978, Calderon-Arguedas et al. 2004). The association with a specific vertebrate may be influenced in part by several reasons including behavior of the host, components of body fluids, and microhabitat created by skin and hair.

Mites associated to fur of mammals have coevolved with their hosts and developed structures that help them clasp on to the specific structure of the host hairs (Labrzycka 2006). Although Listrocarpus saimirii, Listrocarpus cosgrovei, and L. alouattae have been associated with more than one monkey species (Fain 1979, Troyo et al. 2002), most of atopomelid fur mites have been found on one species of primate host. This host specificity may be the result of mite and primate cospeciation. 
Mites belonging to the species L. alouattae had been reported on Alouatta seniculus from Suriname (Fain 1972, Fain 1979) and later on A. palliata from Costa Rica (Troyo et al. 2002). Even though the fur mites were identified as $L$. alouattae in both cases, the mites from these two host species exhibited intraspecific variations (Troyo et al. 2002). L. capucinus and $L$. costaricensis were first described from monkeys in Costa Rica (Troyo et al. 2004) and have not been observed in other monkey species of the same genus. It is also interesting to note that the populations of $S$. oerstedii from Corcovado and Manuel Antonio National Parks are considered different subspecies (S. o. oerstedi and S. o. citrinellus) (Boinski and Sirot 1997), but both harbored the same fur mite species. In this case, the differences at the subspecies level did not seem to affect the relationships between mite and host enough to promote differentiation in the mite populations.

Although very little is known about fur mites of non-human primates, this study shows their distribution in Costa Rica and their strong host-specificity. It is possible that mites of Costa Rican primates are endemic to the areas mentioned, and conservation efforts would impact Listrocapus populations directly. For instance, the most endangered monkey species in Central America is S. oertedii (Rylands 1997), and this threat would extend to its fur mite L. costaricensis. Moreover, it is still unclear if the presence of fur mites can harm the primate hosts, given that some fur mites have been associated with skin lesions and allergic reactions (Troyo et al. 2002, Figueiredo et al. 2004). Atopomelid mites may reveal more about the history and behavior of neotropical primates, and should be studied in more primate species throughout the different geographical areas.

\section{ACKNOWLEDGMENTS}

We thank our students for their assistance during collection and preparation of the samples. This research was supported by Vicerrectoría de Investigación, Universidad de Costa Rica, projects 111-A1-015 and 803-A1-745, and also in part by the Departamento de Investigación, Universidad de Ciencias Médicas.

\section{RESUMEN}

Muy poco se conoce sobre los ectoparásitos, específicamente de los ácaros del pelo, de primates del Nuevo Mundo. En este estudio se buscaron ácaros del pelo en monos Alouatta palliata, Cebus capucinus, Saimiri oerstedii y Ateles geoffroyi provenientes de diferentes áreas de Costa Rica. Se evaluaron 276 monos en total y 51 de ellos se encontraron positivos por ácaros de la familia Atopomelidae. Se identificó Listrocarpus alouattae en el $22.3 \%$ de los A. palliata, Listrocarpus capucinus en el $12.8 \%$ de los C. capucinus y Listrocarpus costaricensis en el $36.8 \%$ de los $S$. oerstedii. El sexo no fue un determinante de la infestación por ácaros, pero la prevalencia de L. alouattae fue significativamente mayor en el Área de Conservación Cordillera Volcánica Central $(\mathrm{p}=0.01)$ y la de L. capucinus fue mayor en el Área de Conservación Pacífico Central $(\mathrm{p}=0.002)$. Estos ácaros del pelo de primates son altamente específicos en relación con su hospedero. Las diferencias en la distribución geográfica podrían deberse al comportamiento e historia de los monos, así como a las condiciones ambientales.

Palabras clave: Atopomelidae, ácaro, Alouatta palliata, Cebus capucinus, Saimiri oerstedii, Ateles geoffroyi, Costa Rica.

\section{REFERENCES}

Bochkov, A.V. \& B.M. OConnor. 2005. Phylogeny and host associations of the fur-mite subgenus Listrophoroides (sensu stricto) Hirst (Acari : Atopomelidae) with an intriguing example of synhospitality on rats of the genus Maxomys. Invertebr. Syst. 19: 437-498.

Bochkov, A.V., P.B. Klimov \& B.M. OConnor. 2005. Fur-mites of the genus Atopomelus Trouessart, 1918 (Acari: Atopomelidae) life-cycle phylogeny and host parasite-associations. Acarologia 45: 207-241.

Boinski, S. \& L. Sirot. 1997. Uncertain conservation status of Squirrel monkeys in Costa Rica, Saimiri oerstedi oerstedi and Saimiri oerstedi citrinellus. Folia Primatol. 68: 181-193.

Boinski, S. \& S.J. Cropp. 1999. Disparate data sets resolve squirrel monkey (Saimiri) taxonomy: implications for behavioral ecology and medical usage. Int. J. Primatol. 20: 237-256.

Brum-Bittencourt, E. \& C.F. Duarte-Rocha. 2003. Hostectoparasite specificity in a small mammal community in an area of Atlantic Rain Forest (Ilha Grande, 
State of Rio de Janeiro), Southeastern Brazil. Mem. Inst. Oswaldo Cruz 98: 793-798.

Calderón-Arguedas, O., A. Troyo \& J. Castro-Ugalde. 2004. Ectoparasitosis por ácaros macronísidos (Gamasida: Macronyssidae). Rev. Costarric. Cienc. Méd. 25: 35-39.

Calderón-Arguedas, O., A. Troyo, M.E. Solano, R. Sánchez, M. Chinchilla \& G.A. Gutiérrez-Espeleta. 2004. Infección por larvas de Alouattamyia baeri (Diptera: Cuterebridae) en monos aulladores, Alouatta palliata (Primates: Cebidae), de la costa caribe de Costa Rica. Neotrop. Primates 12: 21-4.

Chinchilla, M., A. Troyo, O. Guerrero, G.A. GutiérrezEspeleta \& R. Sánchez. 2005a. Presencia de Trypanosoma minasense (Kinetoplastida: Trypanosomatidae) en Alouatta palliata (Primates: Cebidae) de Costa Rica. Parasitol. Latinoam. 60: 90-92.

Chinchilla, M., O.M. Guerrero, G.A. Gutierrez \& R. Sanchez. 2006. Presencia de Plasmodium brasilianum (Apicomplexa, Plasmodidae) en el mono congo (Alouatta palliata, Primates: Cebidae) de Costa Rica. Importancia epidemiológica en relación con el ser humano. Parasitol. Latinoam. 61: 192-196.

Chinchilla, M., O.M. Guerrero, G.A. Gutierrez-Espeleta, R. Sanchez \& I. Valerio-Camps. 2007. Parásitos en monos cariblanca Cebus capucinus (Primates:Cebidae) de Costa Rica. Parasitol. Latinoam. 62: 170-175.

Chinchilla-Carmona, M., O.M. Guerrero-Bermudez, G.A. Gutierrez-Espeleta, R. Sanchez-Porras \& B. Rodriguez-Ortiz. 2005b. Intestinal parasites in howler monkeys Alouatta palliata (Primates: Cebidae) of Costa Rica. Rev. Biol. Trop. 53: 437-445.

Colwell, D.D. \& K. Milton. 1998. Development of Alouattamyia baeri (Diptera: Oestridae) from howler monkeys (Primates: Cebidae) on Barro Colorado Island Panama. J. Med. Entomol. 35: 674-680.

Fain, A. 1972. Nouveaux acariens parasites (Sarcoptiformes et Trombidiformes). Bull. Ann. Soc. R. Belg. Ent. 108: 242-252.

Fain, A. 1979. Les listrophorides d'Amerique neotropicale (Acarina: Astigmates) II. Famille Atopomelidae. Bull. Ins. R. Sci. Nat. Belg. 51: 1-158.

Figueiredo, F.B., T.M.P.Schubach, S.A. Pereira, T. Okamoto, I.B. Dos Santos, L.R. Paes Leme \& J.L.H. Faccini. 2004. Relato de mais 42 casos de linxacariose feline na regiao metropolitan da cidade do Rio de Janeiro, RJ, Brasil. Rev. Bras. Parasitol. Vet. 13: 41-43.
Happel, R. 1986. Seed predation by Ateles geoffroyi (Primates: Cebidae) in Costa Rica. Brenesia 25-26: 261-264.

Jones, C.B. 1983. Do howler monkeys feed upon legume flowers preferentially at flower opening time? Brenesia 21: 41-46.

Krantz, G.W. 1978. A manual of acarology. Oregon State University Book Stores Inc., Corvallis, USA.

Labrzycka, A. 2006. A perfect clasp - adaptation of mites to parasitize mammalian fur. Biol. Lett. 43: 109-118.

Lippold, L.K. 1988. A census of primates in Cabo Blanco absolute nature reserve, Costa Rica. Brenesia 29: 101-105.

Massey, A. 1987. A population survey of Alouata palliata, Cebus capucinus, and Ateles geoffroyi at Palo Verde, Costa Rica. Rev. Biol. Trop. 35: 345-347.

McDaniel, B. 1968. The superfamily Listrophoroidea and the establishment of some new families (Listrophoroidea: Acarina). Acarologia 10: 477-482.

Nunn, C.L., S. Altizer, W. Sechrest, K.E. Jones, R.A. Barton \& J.L. Gittleman. 2004. Parasites and the evolutionary diversification of primate clades. Am. Nat. 164: S90-S103.

Pedersen, A.B., S. Altizer, M. Poss, A. Cunningham \& C.L. Nunn. 2005. Patterns of host specificity and transmission among parasites of wild primates. Int. J. Parasitol. 35: 647-657.

Reed, D.L., J.E. Light, J.M. Allen \& J. Kirchman. 2007. Pair of lice lost or parasites regained: the evolutionary history of anthropoid primate lice. BMC Biology 5: 7.

Renquist, D.M. \& R.A. Whitney. 1987. Zoonoses acquired from pet primates. Vet. Clin. N. Am. Small Anim. Pract. 17: 219-240.

Rodriguez, J. \& F.A. Chinchilla. 1996. Lista de mamíferos de Costa Rica. Rev. Biol. Trop. 44: 877-890.

Rylands, A.B. 1997. Conservation of neotropical primates: threatened species and an analysis of primate diversity by country and region. Folia Primatol. 68: 134-160.

Stuart, M.D., L.L. Greenspan, K.E. Glander \& M.R. Clarke. 1990. A coprological survey of parasites of wild mantled howling monkeys, Alouatta palliata. J. Wild Dis. 26: 547-549.

Stuart, M.D., V. Pendergast, S. Rumfelt, S. Pieberg, L. Greenspan, K.E. Glander \& M.R. Clarke. 1998. 
Parasites of wild howlers (Alouatta spp.). Int. J. Primatol. 19: 493-512.

Troyo, A., M.E. Solano \& O. Calderón-Arguedas. 2004. Two new species of Listrocarpus Fain (Acari Atopomelidae) from Cebus capucinus Linnaeus and Saimiri oerstedii Reinhardt (Primates: Cebidae) in Costa Rica. Syst. Appl. Acarol. Spec. Publ. 18: 1-8.

Troyo, A., M.E. Solano, O. Calderón-Arguedas, M. Chinchilla, R. Sáenz \& G.A. Gutiérrez-Espeleta. 2002. Fur mite, Listrocarpus alouattae Fain (Acari: Atopomelidae), from Alouatta palliata Gray (Primates: Cebidae) in Costa Rica. Int. J. Acarol. 28: 251-5.

Zaldivar, M.E., K.E. Glander, O. Rocha, G. Aguilar, E.
Vargas, G.A. Gutierrez-Espeleta. 2003. Genetic variation of mantled howler monkeys (Alouatta palliata) from Costa Rica. Biotropica 35: 375381 .

Zaldivar, M.E., O. Rocha, K.E. Glander, G. Aguilar, A.S. Huertas, R. Sanchez \& G. Wong. 2004. Distribution, ecology, life history, genetic variation, and risk of extinction of nonhuman primates from Costa Rica. Rev. Biol. Trop. 52: 679-693.

Zucker, E.L., M.R. Clarke, K.E. Glander \& N.J. Scott. 1996. Sizes of home ranges and howling monkey groups at hacienda La Pacifica, Costa Rica: 19721991. Brenesia 45-46: 153-156. 